\title{
YALE NATURAL RADIOCARBON MEASUREMENTS V
}

MINZE STUIVER, EDWARD S. DEEVEY, and L. J. GRALENSKI

Geochronometric Laboratory, Yale University, New Haven, Connecticut

The following list of dates, measured since the publication of Yale IV, includes a few repetitions of published dates, noted as such by the addition of bis to their number. One of these (Y-140 bis) was a new preparation of $\mathrm{CO}_{2}$ from a sample previously measured as acetylene; the others are rechecks of repurified $\mathrm{CO}_{2}$, repeated because instrumental difficulties plagued our laboratory throughout the year beginning in September 1958 and might have affected some dates published in Yale IV. No important differences were found, however. Several measurements of geochemical interest, on lake water and other lacustrine materials for which $\mathrm{C}^{13}$ analyses have been reported (Oana and Deevey, 1960), are not included here but will form the subject of a separate paper.

We have measured the National Bureau of Standards oxalic acid, and find it to have $6 \pm 1$ percent more radiocarbon than our modern wood, after age correction of the latter. This value agrees with that found by other laboratories, and the adoption of a standard equal to 95 percent of the activity of oxalic acid makes no appreciable difference to our dates. The relatively large standard error of our measurement expresses a small uncertainty in the assay of our modern wood, which undergoes a small decline with repeated measurement, probably because of slow outgassing of resin seals that are present in both of our counters. This design has been changed in the new quartz-lined counters that are about to be installed, and more perfect reproducibility is expected. Important though this is for geochemical assays, however, it is insignificant for dates; the major component of error in any single measurement continues to be the counting error of the sample itself.

\section{SAMPLE DESCRIPTIONS}

I. GEOLOGIC SAMPLES

\section{Knob Lake Series, Quebec}

Wood from buried layer of woody peat, $80 \mathrm{~cm}$ thick, underlain and overlain by moss peat, exposed in artificial ditch $\left(54^{\circ} 48^{\prime} \mathrm{N}\right.$ Lat, $60^{\circ} 49^{\prime} \mathrm{W}$ Long), near McGill University Sub-Arctic Research Laboratory, Knob Lake, Schefferville, Quebec, Canada. The section, $235 \mathrm{~cm}$ thick, shows peat of several types, grading downward into gyttja, and overlying clay, till, and bedrock. According to Martin $(1958$, p. 94), the contact between woody peat and the overlying moss peat may be a recurrence horizon, or the woody layer may be the remnant of a forest that destroyed itself by inducing a rise of permafrost. Pollen stratigraphy is being studied by Albert Legault, and megafossils are being studied by H. W. Vogelmann, University of Vermont, Burlington. Coll. 1957 and subm. by P. S. Martin, Geochronology Laboratories, University of Arizona, Tucson.

Y-527. Knob Lake $115 \mathrm{~cm}$

$3880 \pm 120$

Wood near bottom of woody-peat layer, $115 \mathrm{~cm}$ depth. 
Y-528. Knob Lake $40 \mathrm{~cm}$

Wood near top of woody-peat layer, $40 \mathrm{~cm}$ depth.

Comment: if the top of the woody peat is a recurrence horizon, implying a change toward cooler and moister climate, it is of interest that the date is close to that of the classic Grenzhorizont in northern Europe (Overbeck and others, 1957).

\section{Y-689. New Sharon, Maine}

Picea or Larix fragments (id. by W. L. Stern) from lens of organic brown silt overlying greenish-gray till and underlying blue-gray till, exposed (Caldwell, 1959) on N bank of Sandy River (44. $38^{\prime} 30^{\prime \prime}$ N Lat, $70^{\circ} 00^{\prime} 24^{\prime \prime}$ W Long), 0.6 mi NE of New Sharon, Maine. Coll. 1958 by D. W. Caldwell; subm. by A. L. Bloom, Yale University. Comment: another very old sample from under till in southern New England is W-647, > 38,000 (USGS V) from Worcester, Massachusetts, also dated as L-380, > 30,000 (Lamont V).

\section{Y-391. Hamilton City Hall, Ontario}

$11,570 \pm 260$

Wood fragments (id. as dicotyledonous, possibly Populus, by W. L. Stern) ( $43^{\circ} 15^{\prime} 22^{\prime \prime} \mathrm{N}$ Lat, $79^{\circ} 52^{\prime} 27^{\prime \prime} \mathrm{W}$ Long), $37 \mathrm{ft}$ below surface of bar of Lake Iroquois, altitude of sample $80 \mathrm{ft}$ above modern level of Lake Ontario and about $325 \mathrm{ft}$ above sealevel, found in excavation for new City Hall, Hamilton, Ontario, Canada. The wood occurred in a layer of fine sand and silt, interpreted as a lagoon deposit, that was buried by gravel and then by sand as the level of Lake Iroquois, during the last half of the lake's existence, rose at its western end during crustal rebound. The layer contained some pollen (id. by Jaan Terasmae) indicating a climate cooler than today's, and some molluses and ostracods. Coll. 1958 and subm. by P. F. Karrow, Ontario Dept. of Mines, Toronto. Comment: sample dates a late stage of Lake Iroquois, not previously thought to be so old, and therefore apparently antedates the Champlain Sea, the age of which is problematic (Flint, 1956; Terasmae, 1959). The position of the ice margin of Valders time in the Ontario-St.Lawrence lowland is also at issue. Pollen sequences found above Champlain Sea deposits include a spruce-pollen zone, correlated (by Terasmae, 1959) with the upper part of the Durham spruce-pollen zone (Leopold, 1956), known farther south to be of Valders age (Deevey, 1958); but Terasmae also suggested the possibility that this spruce-pollen zone is younger, perhaps of Cochrane age. Dates of organic material in Champlain Sea deposits are urgently needed; the available dates (Y-215, Y-216, Y-233, averaging 10,950 yr; Yale II) are not fully acceptable, because they were based on shell.

\section{Burlington Bar series, Ontario}

Wood from core samples in sand and gravel of Burlington Bearh bar

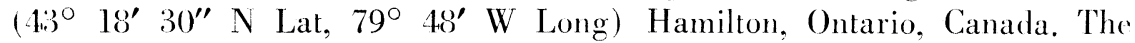
samples and inclosing sand were deposited during the rise of Lake Ontario to its modern level, probably during the early part of the latter half of the rise from low-water stage of the Champlain Sea. Coll. 1958 by Hydro-Electric Power Commission of Ontario; subm. by R. E. Deane, University of Toronto. 
Y-613A. Burlington Bar C-3

$2830 \pm 160$

White pine wood, probably driftwood, core-sample 10, hole C-3, 50 to $51.5 \mathrm{ft}$ depth.

Y-614A. Burlington Bar C-4

$5240 \pm 140$

Hardwood, probably driftwood, core-sample 16, hole C-4, 80 to $81.5 \mathrm{ft}$ depth. Probably older than Y-613A, which came from a higher level in another boring. Comment: the freshening of the Champlain Sea and the rise of Lake Ontario, more rapid at its western than at its eastern end, have long been attributed to crustal unwarping in the region of the eastern outlet (St. Lawrence River). This sample and that from Hamilton City Hall (Y-691, 11,700 \pm 260 , this date list), bracket the age of the Champlain Sea, though within limits so wide as not to settle all controversy.

\section{Squibnocket series, Massachusetts}

Gyttja from base of lake-and-bog deposit, $217 \mathrm{~cm}$ thick, overlain by eolian sand, overlying till (with sharp contact marked by a lag concentrate of pebbles), exposed in seacliff near Squibnocket Point $\left(41^{\circ} 18^{\prime} \mathrm{N}\right.$ Lat, $70^{\circ}$ 47' W Long) Martha's Vineyard, Massachusetts. The unpublished pollen diagram (by J. G. Ogden III) is unclear in its basal portion; the lowest 10 $\mathrm{cm}$, marked by abundant nonarboreal pollen, can be interpreted as belonging to the $\mathrm{V}$ zones described by Ogden (1959), or to a younger postglacial zone (A-1) immediately underlying the lower part of the Durham spruce-pollen zone (A-2) of Leopold (1956). Coll. 1958 by J. G. Ogden III, P. B. Sears, and E. S. Deevey; subm. by Ogden, Ohio Wesleyan University, Delaware, Ohio.

Y-647-1. Squibnocket K-1

$$
12,370 \pm 260
$$

Organic clay-gyttja from 208 to $213 \mathrm{~cm}$ depth.

\section{Y-647-2. Squibnocket K-2}

$12,310 \pm 320$

More sterile clay-gyttja from 213 to $216 \mathrm{~cm}$, overlying till.

\section{Y-647-3. Squibnocket K-3}

$12,350 \pm 260$

Clayey till with some organic remains from 216 to $219 \mathrm{~cm}$ depth. Comment: a sample from the bottom inch of the deposit, coll. by Clifford Kaye, was dated by the U. S. Geological Survey Laboratory (W-710, 12,700 \pm 300 , USGS V). The implication is clear that the bottom zones are not the $\mathrm{V}$ zones of Ogden but belong to zone A-1.

Y-646-1. Duarte's Bog, Martha's Vineyard, Zone V-3 $9910 \pm 440$

Gyttja from 501 to $513 \mathrm{~cm}$ depth, assigned to zone V-3 (Ogden, 1959) at the site of Ogden's boring MV-7, Duarte's Bog (4.1 $27^{\prime} \mathrm{N}$ Lat, $70^{\circ} 37^{\prime} \mathrm{W}$ Long), Martha's Vineyard, Massachusetts. Sample was a composite of parts of three samples taken with Hiller borer below a sandy layer (zone V-4) that was removed each time by soil auger before sampling was possible. Coll. 1958 by J. G. Ogden III and E. S. Deevey; subm. by Ogden, Ohio Wesleyan University, Delaware, Ohio. Comment: because of the difficulty of sampling the gyttja, it is possible that younger carbon was introduced into one or more boreholes and that the composite sample was thus contaminated. However, unexpectedly young dates have been obtained below the lower part of the 
Durham spruce-pollen zone in another boring on Block Island (W-877, 10,500 \pm 210 , USGS V) and in an exposed section at Squibnocket on Martha's Vineyard (this date list, and W-710, $12,700 \pm 300$, USGS V). Some doubt is therefore cast on the interpretation of Ogden (1959) that the $\mathrm{V}$ zones are older than the ecologically similar $\mathrm{T}$ zones at Totoket Bog, Connecticut (Deevey, 1958).

\section{Laguna de San Rafael series, Chile}

Wood and peat from various sites in the Laguna de San Rafael district, southern Chile, the northernmost region where Andean glaciers reach sealevel, coll. 1959 by American Geographical Society expedition for study of glaciation and recent deglaciation. Preliminary technical reports are available in mimeographed form (Muller, 1959; Lawrence and Lawrence, 1959; Heusser, 1959). Subm. by C. J. Heusser, American Geographical Society, New York 32, N. Y.

Y-733. San Rafael Glacier 1

$180 \pm 80$

Nothofagus (probably N. nitida) log imbedded in till, about 200 yd S of San Rafael Glacier ( $46^{\circ} 42^{\prime}$ S Lat, $73^{\circ} 55^{\prime}$ W Long). The till was probably deposited before A.D. 1890, during the most recent advance of the glacier. Coll. by D. B. Lawrence.

Y-734. San Rafael Glacier $2 \quad 290 \pm 80$

Root, in situ, overlain by forest debris and till about $75 \mathrm{yd} \mathrm{S}$ of San Rafael Glacier $\left(46^{\circ} 42^{\prime} \mathrm{S}\right.$ Lat, $73^{\circ} 55^{\prime} \mathrm{W}$ Long). The till was probably deposited before A.D. 1890, during the most recent advance of the glacier. Coll. by D. B. Lawrence.

\section{Y-735. San Rafael Glacier 3}

$405 \pm 100$

Trunk (probably Nothofagus sp.) in nearly erect position, protruding about $10 \mathrm{ft}$ from between rocks on surface of till, about $575 \mathrm{yd}$ from (inside from) modern terminal moraine $\left(46^{\circ} 39^{\prime} \mathrm{S}\right.$ Lat, $73^{\circ} 54^{\prime} \mathrm{W}$ Long) $\mathrm{N}$ of San Rafael Glacier. The tree was probably not in situ; it was probably deposited in the till but eroded out by a stream crossing the till body. Coll. by D. B. Lawrence.

\section{Y-736. Istmo de Ofqui 4}

$730 \pm 120$

Twigs from peaty layer in lowermost $1 \mathrm{ft}$ of shingle bed, $6 \mathrm{ft}$ thick, overlying till in shore bluff $\left(46^{\circ} 41^{\prime} \mathrm{S}\right.$ Lat, $74^{\circ} 03^{\prime} \mathrm{W}$ Long) $1500 \mathrm{ft} \mathrm{SE}$ of Istmo de Ofqui Canal entrance. The origin of the shingle is in doubt; it resembles a beach deposit. The sample provides a minimum age for the till, deposited during the younger of two advances of San Rafael Clacier. Coll. by E. H. Muller and C. J. Heusser.

Y-737. San Rafael Glacier $5 \quad \mathbf{5} \quad \mathbf{6 8 5 0} \pm \mathbf{2 0 0}$

Nothofagus wood, compressed but fresh, with bark, in peat under till of recent advance of San Rafael Glacier $\left(46^{\circ} 40^{\prime} \mathrm{S}\right.$ Lat, $73^{\circ} 53^{\prime} \mathrm{W}$ Long), about $100 \mathrm{yd}$ downstream $(\mathrm{N})$ from $\mathrm{N}$ side of glacier terminus. The glacier was less extensive than at present when the tree grew; the sample dates part of the nonglacial interval at the locality. Pollen stratigraphy at the side is under investigation. Coll. by E. H. Muller. 
Y-738-2. Istmo de Ofqui $\mathbf{2 - 2 3}$

$3740 \pm 400$

Peat sample 2.23 from near bottom of postglacial section, $7.25 \mathrm{ft}$ deep, taken by boring in bottom of a lake $\left(46^{\circ} 40^{\prime} \mathrm{S}\right.$ Lat, $74^{\circ} 04^{\prime} \mathrm{W}$ Long $), 2100 \mathrm{ft}$ $\mathrm{N}$ of Istmo de Ofqui Canal. The sampled section overlies laminated sediments, presumably deposited when the margin of San Rafael Glacier was nearby, and not long after its retreat from the moraine on which the lake is situated and which nearly surrounds Laguna de San Rafael. Pollen stratigraphy at the site is under investigation. Coll. by C. J. Heusser and Shoji Horie. Comment: sample Y-738-1, from 83 to 84 in. depth, was lost in a laboratory accident, and sample 2-23, from 82 to 83 in. was substituted. Alcohol preservative was baked out: sample was diluted with anthracite $\mathrm{CO}_{2}$ before dating.

\section{Y.739. Rio Tempanos 7A}

$3720 \pm 170$

Peat, 36 in. depth, from section 73 in. deep, exposed on $\mathrm{E}$ bank of Rio Tempanos, the only tidal connection of Laguna de San Rafael, about $3300 \mathrm{ft}$ $\mathrm{S}$ of mouth of Rio Chivo $\left(46^{\circ} 36^{\prime} \mathrm{S}\right.$ Lat, $73^{\circ} 58^{\prime} \mathrm{W}$ Long), $2 \mathrm{mi} \mathrm{N}$ of moraine bounding Laguna de San Rafael. The peat section overlies finely laminated silt, apparently lacustrine; its base postdates the draining of a lake that was formed after retreat of Guala Glacier from the outermost position of its piedmont stage. Pollen stratigraphy at the site is under investigation. Coll. by E. H. Muller and C. J. Heusser.

\section{Y-740. Rio Tempanos 7B}

Peat, 54 in. depth, from section described under Y-739.

\section{Y-741. Rio Tempanos 7C}

$3180 \pm 200$

Peat, 73 in, depth, from basal contact of section described under Y-739, where roots penetrate underlying silt.

General comment (C.J.H.) : close agreement between the ages of the base of this section and sample Y.738-2 suggests contemporaneous retreat of Guala and San Rafael Glaciers. Apparent contemporaneity of samples Y-739, 740, 741 is not understood. It is possible that the approximately $36 \mathrm{in}$. of peat between the base and the $36 \mathrm{in}$. depth in the section formed extremely rapidly. Peat stratigraphy supports such a possibility, since sediments consist chiefly of poorly humified fibrous material. Pollen stratigraphy may clarify this point.

\section{Y-633. Lena River Mammoth}

Skin of mammoth (Mammuthus primigenius), believed to be from the specimen found in A.D. 1799, thawing from permafrost in the delta of Lena River $\left(72^{\circ} \mathrm{N}\right.$ Lat, $130^{\circ} \mathrm{S}$ Long), near Cape Baikow, Siberia, and described by Michael Adams in 1806. Tolmachoff (1929) gave an account of this and other discoveries. Evidence that the specimen was part of the Lena River mammoth, most of which is now in Leningrad, consists of an entry, undated but one of those collated by O. C. Marsh, in the catalogue of the Peabody Museum, Yale University: "678 [now 10678]. Elephas primigenius Blumb. Siberia. Post Pliocene. Donated by R. Sanford, Esq. (New York). B. Silliman Jr. Original in the Imperial Museum, Petersberg. 1 frag. epidermis." Subm. by C. O. Dunbar, Yale University. Comment: although some mammoth carcasses found in similar circumstances are believed to be of late-glacial or 
early postglacial age, other mammoth remains are certainly older (see Heintz, 1958, for criticism of recent work on the Beresovka mammoth, and Pavlovskij, 1956, for an account of the Mamontova find on the Taimyr peninsula). The date suggests that the Lena River specimen, at least, was interglacial; like the Mamontova carcass, it may have been preserved in nonglacial (bog) sediments before being frozen into permafrost.

\section{Kwanto series, Japan}

Wood from above and below parts of the Kwanto "loam" (volcanic ash) formation, near Tokyo, Japan. According to an unpublished memorandum by Shoji Horie (see also Kanto Loam Research Group, 1956, 1957) the Kwanto volcanic-ash formation, of late Pleistocene age and mainly composed of volcanic ash and of alluvium and colluvium derived from it, is widespread in the Kwanto district surrounding Tokyo and consists of at least four units, each named for the youngest marine terrace on which it was deposited during pauses in progressive uplift. In order of age and of successively lower altitude above present sealevel, the four volcanic-ash-covered terraces are Tama (with four superimposed units), Shimosueyoshi (with three superimposed units), Musashino (with two superimposed units), and Tachikawa (with one unit). Younger and lower terraces, notably the Numa terrace, which consists of marine (partly coral-reef) deposits implying sea-surface temperatures as high or higher than today's, are not covered by Kwanto volcanic ash. The Kwanto and other Late Pleistocene volcanic-ash formations contain Paleolithic artifacts and may contain extinct vertebrates, as well as cool-climate fossil floras. The stratigraphic boundary between Upper Pleistocene and Holocene stages is therefore thought to lie somewhere between the top of the Kwanto volcanic ash and the bottom of the Numa formation, but the contact has not been observed. The Ekoda conifer bed, dated as part of this series, postdates the Tachikawa member of the Kwanto volcanic-ash and is the youngest coolclimate conifer bed known in the Tokyo district, but similar floras elsewhere in Japan are younger (see Y.594, this date list), and the Ekoda bed is best regarded as Late Pleistocene, not Holocene.

\section{Y-591. Ekoda}

$23,700 \pm 600$

Wood from the conifer bed, exposed by drainage operations in 1936, Nakano ( $35^{\circ} 43^{\prime} \mathrm{N}$ Lat, $139^{\circ} 42^{\prime} \mathrm{E}$ Long), Tokyo, Japan. The extensive fossil flora, described by Miki (1938), contains sereral species not now growing below $1500 \mathrm{~m}$ altitude. The exposure is no longer visible and recent borings have failed to encounter the bed. The inclosing and overlying deposit, considered to be Kwanto loam by Miki, is now thought to have heen alluvium, partly filling a valley cut in the Tachikawa (youngest) unit of the Kwanto volcanic-ash formation. Coll. and subm. by H. Ozaki, National Science Museum, Ueno Park, 'Tokyo, through Cilbert Corwin, Pacific Gcologic Surveys Section, U. S. Gcological Survey, Tokyo, Japan.

Y-640. Shimosueyoshi

Wood, imbedded several $\mathrm{m}$ down in the Shimosueyoshi (marine sand) formation of the Shimosueyoshi terrace, second-oldest of the series of four marine terraces in the Tokyo-Yokohama district, exposed in an outcrop at $5 \mathrm{~m}$ 
altitude, Kase, Hiyoshi (35 $33^{\prime} \mathrm{N}$ Lat, $139^{\circ} 40^{\prime} \mathrm{E}$ Long), Yokohama city, Kanagawa Prefecture, Japan. The Shimosueyoshi formation is overlain by Kwanto volcanic ash, undifferentiated at the site but presumed to be composed of the youngest three units of the Kwanto volcanic-ash formation, which consists of four units. Thus most of the Kwanto deposit is bracketed in age by this sample and Y-591. Coll. 1954 hy Arata Sugimura, Tokyo University, and subm. by Shoji Horie, Kyoto University.

\section{Y.594. Hanaizumi, Japan}

$15,850 \pm 360$

Wood from near lowest part of conifer bed, interbedded with sand, about $4 \mathrm{~m}$ below surface, Hanaizumi (38 $50^{\circ} \mathrm{N}$ Lat, $141^{\circ} 10^{\prime} \mathrm{E}$ Long), Iwate Prefecture, in the $\mathrm{E}$ part of $\mathrm{N}$ Honshu, Japan. Plant fossils imply a climate colder than today's; accompanying vertebrate remains, believed to have been artificially worked (Matsumoto and Mori, 1956), belong to several extinct species, including fossil elephant (Palaeoloxodon tokunagai junior Mat). Coll. and subm. by H. Ozaki, National Science Museum, Ueno Park, Tokyo. Comment: the conifer bed lies near the surface, overlain by modern soil with Yayoi (?) potsherds, and has no known stratigraphic relation to a volcanicash layer. The date confirms the expected antiquity of a layer containing extinct mammals. but is younger than that of the climatically similar Ekoda hed (Y-591, 23,700 \pm 600 , this date list), and is equally unsuitable as marking the top of the Upper Pleistocene stage in Japan. New excavations by Kunio Kobayashi have clarified the stratigraphy and resulted in revision of the identification of mammals; new radiocarbon samples have been sent to the Stockholm laboratory.

Y-641. Tocchu, Japan

$1590 \pm 140$

Picea wood (id. by Aya Yamanouchi) from $540 \mathrm{~cm}$ below surface, the horizon of the Lower Picea bed, Tocchu (36 $26^{\prime} \mathrm{N}$ Lat, $137^{\circ} 49^{\prime} \mathrm{E}$ Long), altitude $600 \mathrm{~m}$ above sealevel, $12 \mathrm{~km} \mathrm{~N}$ of Matsumoto, Nagano Prefecture, Japan. The deposit is alluvial or colluvial in origin, probably consisting in part of reworked Shinshu loam, the younger member of which is known elsewhere in the district to contain artifacts of nonceramic cultures. Some tree stumps of the Lower Picea bed, which collectively implies a mean annual temperature about $5^{\circ} \mathrm{C}$ lower than today's, were found rooted in situ, accompanied by remains of the extinct giant deer (Euryceros sp.). Pottery of oldest Jomon type occurred at about $110 \mathrm{~cm}$ depth in the section, which is described by Kobayashi (1958). Coll. and subm. by Kunio Kobayashi, Shinshu University, Matsumoto, Japan. Comment: obviously too young to be acceptable; new excavations are planned.

\section{Dura River series, Uganda}

Carhonized wood and peaty material imbedded in and overlain by travertine limestunes, exposed in valley of Dura River $\left(0^{\circ} 12^{\prime} \mathrm{N}\right.$ Lat, $30^{\circ} 18^{\prime} \mathrm{E}$ Long) and its tributary, the Dwemkorebe River, western Uganda. The travertines occur interbedded with apparently lacustrine limestones, laid down when the level of Lake George in this region stood 70 to $100 \mathrm{ft}$ above its present altitude $2997 \mathrm{ft}$ above o.D. (Barnes, 1956). The deposits, with maximum observed thickness of $50 \mathrm{ft}$, overlie fluvio-lacustrine gravel. Coll. 1957 by $R$. 
Seal; subm. by W. W. Bishop by permission of the Director, Geological Survey of Uganda, Entebbe.

Y-568. Dura River EA-318

$7530 \pm 450$

Carbonized wood imbedded in travertine, coll. from a spoil dump near the main $(E)$ outcrop where the limestones attain maximum observed thickness.

Y-611. Dwemkorebe River EA-519

Modern

Carbonized wood and peaty material from below the limestone, occurring along the Dwemkorebe valley. Comment (W.W.B): if the limestones were in part lacustrine, a relative upwarp of 40 to $50 \mathrm{ft}$ must have taken place since their formation, as there is firm evidence $\mathrm{SW}$ of Lake George $\left(0^{\circ} 10^{\prime}\right.$ $\mathrm{N}$ Lat, $30^{\circ} 0^{\prime} \mathrm{E}$ Long), that the lake was within $30 \mathrm{ft}$ of its present level prior to the deposition of the Katwe volcanic ash, dated by de Heinzelin (1957, p. 18) as ca. 8000 B.P. The ash is postdated by local faults; hence comparatively recent tectonic activity is confirmed for the region. However, it is possible that in addition to the travertine much of the limestone arises from subaerial spring action, as suggested by abundant remains of the land snail Limicolaria sp. [and by the modern or slightly "supermodern" $\mathrm{C}^{14}$ assay of Y-611, implying equilibration with atmospheric $\mathrm{CO}_{2}$ - authors].

\section{Y-688. Hippo Bay Cave, Entebbe, Uganda}

$3720 \pm 120$

Charcoal from lens of sand, 9 in. thick, interpreted as part of emerged beach, overlying wave-cut platform of lateritic ironstone, overlain by gravel ( 1 to 2 in.) and then by pottery-rich occupation layers, in small cave on $\mathbb{W}$ headland of Hippo Bay $\left(0^{\circ} 03^{\prime} \mathrm{N}\right.$ Lat, $32^{\circ} 27^{\prime} \mathrm{E}$ Long), Entebbe, Uganda, at altitude $8 \mathrm{ft}$ above Lake Victoria (Brachi, 1960). The charcoal is presumably of cultural origin but has been rounded by wave action; it dates the last and lowest former high shoreline (ca. $12 \mathrm{ft}$ above lake level) of Lake Victoria (Bishop, 1960, p. 93) ; the high lake level is considered not to have resulted from crustal movement but probably marks a stillstand in downcutting of the lake outlet at Jinja. Coll. 1957 and subm. by W. W. Bishop, Geological Survey of Uganda, Entebbe; Survey sample W. W. 441.

\section{ARCHAEOLOGIC SAMPLES}

\section{Y-655-1. Kayuk, Alaska}

Modern

Charcoal and fragments of charred wood from a hearth in quadrants A and B, trench 2, Kayuk site, Anaktuvuk Pass $\left(68^{\circ} 08^{\prime} \mathrm{N}\right.$ Lat, $151^{\circ} 43^{\prime} \mathrm{W}$ Long), Brooks Range, Alaska. The sample, associated with artifacts of the Kayuk complex (Campbell, 1959), was distributed evenly from 2.5 to 6 in. below present ground surface. Coll. 1957 and subm. by J. M. Campbell, Department of Sociology and Anthropology, George Washington University, Washington, D. C. Comment: the cultural complex is believed to be younger than the Denbigh Flint Complex and older than the Ipiutak culture. The sample is obviously unreliable as a date for the culture; presumably it lay too close to present ground surface in a region of extreme frost climate. 
Y-656-1. Okiotak, Alaska

Modern

Charcoal fragments from a fire area, quadrant $\mathrm{E}$, trench 2, Okiotak site, Anaktuvuk Pass $\left(68^{\circ} 08^{\prime} \mathrm{N}\right.$ Lat, $151^{\circ} 43^{\prime} \mathrm{W}$ Long), Brooks Range, Alaska. The sample, associated with artifacts of the Okiotak complex (J. M. Campbell, ms. in preparation), believed to represent a relatively late prehistoric culture, was evenly distributed from 2 to 5 in. below present ground surface. Coll. 1957 and subm. by J. M. Campbell, Department of Sociology and Anthropology, George Washington University, Washington, D. C. Comment: obviously unreliable as a date for the culture, presumably because the sample lay too close to present ground surface in a region of extreme frost climate.

\section{Y-644. Ostoyohualco, Teotihuacan, Mexico $\quad 1930 \pm 80$}

Charcoal, accompanied by sherds of Teotihuacan I culture, from Pyramid B, Ostoyohualco $\left(19^{\circ} 40^{\prime} \mathrm{N}\right.$ Lat, $98^{\circ} 50^{\prime} \mathrm{W}$ Long), Teotihuacan, Mexico. Sample occurred $8 \mathrm{~m}$ from mouth of tunnel, next to a post hole, $5.55 \mathrm{~m}$ from burial datum point, bearing $\mathrm{S} 10^{\circ} 30^{\prime} \mathrm{W}$ of magnetic $\mathrm{N}$, minus $69 \mathrm{~cm}$ from auxiliary point II on upper step of second substructure staircase, inside pyramid and over bedrock. Coll. 1958 and subm. by Carmen Cook de Leonard, Centro de Investigaciones Antropológicas, Madero 27, Mexico 1, D. F. Comment: in excellent agreement with current concepts of Teotihuacan chronology. St.-162, $1720 \pm 65$ (Stockholm I), from Teotihuacan II-III and crossdated by occurrence of Tzakol pottery from the Maya area, is younger; dates of late pre-classic cultures contemporary with or antedating Teotihuacan I are identical or slightly older (Y-437, $1925 \pm 60$, Yale IV; M-663, $2040 \pm 200$, Michigan III; C-202, $2565 \pm 200$, Chicago I). Chicago dates from the precinct of Teotihuacan itself are not acceptable, but one of the two discordant runs of C-422 (Atetelco, pub. as 2244 \pm 180 , Chicago I) gave the reasonable figure of $1878 \pm 200$ for Teotihuacan II.

\section{Y-558. Alumbrera, Argentina}

$1630 \pm 60$

Charcoal from room 2, Unidad B site, Alumbrera $\left(27^{\circ} 38^{\prime} \mathrm{S}\right.$ Lat, $66^{\circ}$ 06' W Long), Dept. of Andalgala, Prov. of Catamarca, Argentina. The associated culture is Condorhuasi, Alamito phase. Coll. 1957 by A. Rex González and W. Harvey; subm. by González, University of Cordoba, Cordoba, Argentina. Comment: the age of Condorhuasi culture is not fixed stratigraphically, and the Hualfin valley sites where it occurs, and that of Alumbrera, are probably peripheral to its main area. The collector's earlier opinion (González, $1955,1956)$ that it was younger than La Aguada and La Cienaga cultures was revised (González, 1957) in the light of the late date for La Aguada (L-307, $1130 \pm 90$, Lamont IV; confirmed by U-155, $1180 \pm 85$, Uppsala II), and the date is not unexpected.

Y-559. Corral de Ramas, Argentina

$\mathbf{5 9 0} \pm \mathbf{5 0}$

Charcoal from pit-house no. 1, Corral de Ramas $\left(27^{\circ} 35^{\prime} 18^{\prime \prime} \mathrm{S}\right.$ Lat, $67^{\circ}$ $38^{\prime} 18^{\prime \prime} \mathrm{W}$ Long), Dept. of Belen, Prov. of Catamarca, Argentina. The associated culture is Belen, phase A, described by González (1955). Coll. 1952 by A. Rex González and Domingo Garcia; subm. by González, University of Cordoba, Cordoba, Argentina. Comment: another sample from this pit-house was dated by the Uppsala laboratory (U-153, $795 \pm 80$, Uppsala II) . 
Y-560. Cerrito Colorado, Argentina

Charcoal from room 3, Cerrito Colorado site, La Cienaga $\left(27^{\circ} 42^{\prime} 18^{\prime \prime}\right.$ S Lat, $67^{\circ} 59^{\prime} 11^{\prime \prime}$ W Long), Dept. of Belen, Prov. of Catamarca, Argentina. The associated culture is Belen, phase B, considered very recent but pre-Inca (González, 1955). Coll. 1952 by A. Rex González and Domingo Garcia; subm. by González, University of Cordoba, Cordoba, Argentina. Comment: another sample from this site and phase dated by the Uppsala laboratory (U-154, 580 \pm 80 , Uppsala II) provides a more acceptable date for the culture.

Y-570. Lanet II, Kenya

$375 \pm 100$

Charcoal from hearth under a ground surface, developed on deposits of former Lake Nakuru and buried by an artificial earthwork at Lanet $\left(0^{\circ} 18^{\prime} \mathrm{S}\right.$ Lat, $36^{\circ} 07^{\prime} \mathrm{E}$ Long), Nakuru, Kenya. The inclosing soil is rich in organic matter and charcoal; cultural remains associated with charcoal on the overlying soil surface include decorated pottery of the Lanet culture (related to the Hyrax Hill, NE Village, Neolithic assemblage; Leakey, 1945) and bones of domestic animals (Posnansky, in press). Coll. 1957 and subm. by Merrick Posnansky, Uganda Museum, Kampala, Uganda. Comment: charcoal near the surface of long-uninhabited sites is notoriously likely to have been injected into the site by later campers, but the circumstances of this find show that the latest campers antedated the construction of the earthwork, which is of a type associated here with occupation hollows carrying decorated pottery of the Lanet culture. Field observations suggest that the hollows are dug into and are contemporaneous with or postdate the earthwork. The date throws no light on the age of the former high level of Lake Nakuru.

\section{Y-722. Graniteside, Southern Rhodesia $\quad 670 \pm 100$}

Charcoal scraped from inside pots in ancient cemetery, Graniteside $\left(17^{\circ}\right.$ $50^{\prime} \mathrm{S}$ Lat, $31^{\circ} 05^{\prime} \mathrm{E}$ Long), Salisbury, Southern Rhodesia. The pots appear to be of Bantu type but may be more primitive, and occurred in large numbers in individual burials. Beads, metal, and stone artifacts also accompanied the skeletal material (Goodall, in press; Trevor Jones, in press; Tobias, 1959). Coll. 1958-1959 and subm. by Mrs. E. Goodall, Queen Victoria Museum, Salisbury, Southern Rhodesia. Comment: the date seems reasonable, though the skeletal remains are believed to be non-Bantu and an older date (about A.D. 700) might therefore have been anticipated.

\section{REPEATED MEASUREMENTS}

\section{Y-140 bis. Mount Garibaldi, British Columbia}

$\mathbf{5 2 6 0} \pm \mathbf{2 0 0}$

Yellow-cedar wood, rooted in place, from an old forest on a barren nunatak, covered until about A.D. 1940 by the glacier on E side of Mount Garibaldi ( $49^{\circ} 52^{\prime} \mathrm{N}$ Lat, $122^{\circ} 59^{\prime} \mathrm{W}$ Long), southwestern British Columbia, Canada. Described by Mathews (1951). Coll. and subm. by W. H. Mathews, University of British Columbia, Vancouver. Comment: the published measurement, made by the acetylene method, was $5850 \pm 180$ (Yale II). The revised measurement is probably more nearly correct; both are acceptable as dating a part of Hypsithermal time. 


\section{Y-355A bis. Rancho la Brea, no. 2, untreated}

$15,400 \pm 300$

Wood from increment core bored in trunk of tree excavated in 1913 at Pit 3, Section D, 4 to $12 \mathrm{ft}$ depth, Rancho La Brea, Los Angeles $\left(34^{\circ} 03^{\prime}\right.$ $45^{\prime \prime}$ N Lat, $118^{\circ} 21^{\prime}$ W Long), California. Another portion of this core, 44.5 in. above base of trunk, was xylol-washed to remove tar, and gave 13,890 \pm 280 (Y-355B, Yale IV); this sample was untreated. Subm. by Hildegarde Howard, Los Angeles County Museum. Comment: measurement repeated because of possible instrumental difficulties during preparation of Yale IV. The published age is $14,110 \pm 420$, not significantly different from the revised figure. The La Jolla laboratory has analyzed the same tree trunk more recently: LJ $55,14,400 \pm 300$, La Jolla I. Tar extracted from the wood (LJ-89, $>28,000$, La Jolla I) is infinitely old, as expected. A full discussion is given by Howard (1960).

Y.425 bis. Pascagoula, Mississippi, 7 to 12 in. $\quad 9770 \pm 210$

Wood fragments from 7 to 12 in. depth in submarine core $7796-\mathrm{H}$, Gulf Research and Development Co. $\left(29^{\circ} 50^{\prime} 23^{\prime \prime}\right.$ N Lat, $88^{\circ} 07^{\prime} 48^{\prime \prime}$ W Long), off Pascagoula, Mississippi. Subm. by B. B. Cox, Gulf Research and Development Co., Pittsburgh 30, Pennsylvania. Comment: measurement repeated because of possible instrumental difficulties during preparation of Yale IV. The published age was $10,120 \pm 120$, not significantly different from the revised figure.

\section{Y-626 bis. Chichen Itza}

$1140 \pm .100$

Wood from beam inside $\mathrm{S}$ doorway of temple building (El Castillo), Chichen Itza $\left(20^{\circ} 41^{\prime} \mathrm{N}\right.$ Lat, $88^{\circ} 34^{\prime} \mathrm{W}$ Long), Yucatan, Mexico. Coll. 1958 by Alberto Ruz; subm. by Carnegie Institution of Washington. Comment: measurement repeated because of possible instrumental difficulties during preparation of Yale IV. The published age was $1160 \pm 70$, not significantly different from the revised figure.

\section{REFERENCES}

Date lists:

$\begin{array}{ll}\text { Chicago I. } & \text { Arnold and Libby, 1951 } \\ \text { Chicago III. } & \text { Libby, 1952 } \\ \text { La Jolla I. } & \text { Hubbs, Suess, and Bien, 1960 } \\ \text { Lamont IV. } & \text { Broecker and Kulp, 1957 } \\ \text { Lamont V. } & \text { Olson and Broecker, 1959 } \\ \text { Michigan III. } & \text { Crane and Griffin, 1958 } \\ \text { Stockholm I. } & \text { Östlund, 1957 } \\ \text { Uppsala II. } & \text { Olsson, 1960 } \\ \text { USGS V. } & \text { Rubin and Alexander, 1960 } \\ \text { Yale II. } & \text { Preston, Person, and Deevey, 1955 } \\ \text { Yale IV. } & \text { Deevey, Gralenski, and Hoffren, 1959 }\end{array}$

Arnold, J. R., and Libby, W. F., 1951, Radiocarbon dates: Science, v. 113, p. 111-120.

Barnes, J. W., 1956, The limestones of the Lake George depression: Geol. Survey Uganda Rec, 1954, p. $55-59$.

Bishop, W. W., 1960, A review of the Pleistocene stratigraphy of the Uganda Protectorate: C.C.T.A., Proc. Meeting C.C.T.A. Regional Committees, Geology, Leopoldville, 1958, p. 91-105. London, C.C.T.A.

Brachi, R. M., 1960, Uganda Jour., March 1960.

Broecker, W. S., and Kulp, J. L., 1957, Lamont natural radiocarbon measurements IV: Science, v. 126 , p. $1324-1334$. 
Caldwell, D. W., 1959, Glacial lake and glacial marine clays of the Farmington area, Maine: Maine Geol. Survey, Spec. Geol. Stud. Ser. 3, 48 p., 3 folded pls.

Campbell, J. M., 1959, The Kayuk complex of Arctic Alaska: Am. Antiquity, v. 25, p. 94 105.

Crane, H. R., and Griffin, J. B., 1958, University of Michigan radiocarbon dates III: Science, v. 128, p. 1117-1123.

Deevey, E. S., 1958, Radiocarbon-dated pollen sequences in eastern North America: Geobot. Inst. Rübel, Zürich, Veröffentl., no. 34, p. 30-37.

Deevey, E. S., Gralenski, L. J., and Hoffren, Väinö, 1959, Yale natural radiocarbon measurements IV: Am. Jour. Sci. Radioc. SuPP., v. 1, p. 144-172.

Flint, R. F., 1956, New radiocarbon dates and late-Pleistocene stratigraphy: Am. Jour. ScI., v. 254 , p. $265-287$.

González, A. R., 1955, Contextos culturales y cronología relativa en el área central del N.O.Argentino (Nota preliminar): Anal. Arqueol. y Etnol., v. 11, p. 1-32, 10 pls. para su estudio): Runa, v. 7, pt. I, p. 37-86.

método 1957, Dos fechas de la cronología arqueologica Argentina obtenidas por et método de radiocarbón: Univ. Nac. del Litoral [Rosario, Argentina], Inst. de Antropologia, $19 \mathrm{p}$.

Goodall, E., in press, Report on an ancient burial ground, Salisbury, Southern Rhodesia: Pan-African Cong. on Pre-History, 4th, Leopoldville, Proc.

Heintz, Anatol, 1958, Om pollenanalyse av mageinnholdet fra Beresovka-mammuten; On the pollen analysis of the stomach contents of the Beresovka mammoth: Blyttia, v. 16, p. $122-142$.

Heinzelin, J. de, 1957, Les Fouilles d'Ishango: Exploration du Parc Nat. Albert, Mission J. de Heinzelin, 1950, fasc. 2. Brussels, Inst. des Parcs Nat. du Congo Belge.

Heusser, C. J., 1959, Research on late-Pleistocene environments of southern Chile: Am. Geog. Soc., Semi-Annual Status Rept., Contract Nonr-641(04) [processed].

Howard, Hildegarde, 1960, Significance of Carbon-14 dates for Rancho La Brea: Science, v. 131, p. 712-714.

Hubbs, C. L., Suess, H. E., and Bien, H. E., 1960, Scripps Institution of Oceanography radiocarbon measurements I: Am. Jour. SCI. Radioc. Supp., v. 2, p. 197-223.

Kanto Loam Research Group, 1956, Problems on the Kanto loam: Geol. Soc. Japan Jour., v. 62 , p. 302-316 [Japanese, with English summary].

1957, On the relation between Ekoda conifer-bed and Kanto loam: Geol. Soc. Japan Jour., v. 63, p. 725-727 [Japanese].

Kobayashi, Kunio, 1958, Quaternary glaciation of the Japan Alps: Shinshu Univ., Fac. Liberal Arts \& Sci., Jour., no. 8, pt. II, p. 13-67, 12 pls.

Lawrence, D. B., and Lawrence, E. G., 1959, Recent glacier variations in southern South America: Am. Geog. Soc. Southern Chile Exped., Tech. Rept. [to Office of Naval Research], Contract Nonr-64l (04) [processed].

Leakey, M. D., 1945, Report on the excavation at Hyrax Hill, Nakuru, Kenya Colony, 1937-8: Royal Soc. South Africa Trans., v. 30, pt. IV, p. 271-409.

Leopold, E. B., 1956, Two late-glacial deposits in southern Connecticut: Nat. Acad. Sci. Proc., v. 52, p. 863-867.

Libby, W. F., 1952, Chicago radiocarbon dates, III: Science, v. 116, p. 673-681.

Mathews, W. H., 1951, Historic and prehistoric fluctuations of alpine glaciers in the Mount Garibaldi map-area, southwestern British Columbia: Jour. Geology, v. 59, p. 357-380, 7 figs.

Martin, P. S., 1958, Geoecological observations in New Quebec, in Drummond, R. N., ed., Scientific studies in the Labrador peninsula: McGill Sub-Arctic Research Papers, no. 4, p. 93-97.

Matsumoto, H., and Mori, H., 1956, On the mammals of the very Late-Pliocene fossiliferous zone at Kanamori, Hanaizumi, Nishi-iwai District, Province of Rikichu: Zool. Mag. [Japan], v. 65, p. 239-249 [English summary].

Miki, Shigeru, 1938, On the change of flora of Japan since the Upper Pliocene and the floral composition at the present: Jap. Jour. Botany, v. 9, p. 213-251, pl. 3, 4.

Muller, E. H., 1959, Glacial geology of the Laguna San Rafael area: Am. Geog. Soc. Southern Chile Exped., Tech. Rept. [to Office of Naval Research], Contract Nonr$6411(04)$ [processed].

Oana, Shinya, and Deevey, E. S., 1960, Carbon 13 in lake waters, and its possible bearing on paleolimnology: Am. Jour. Scr., v. 258 A, (Bradley volume), p. 253-272.

Ogden, J. G., III, 1959, A late-glacial pollen sequence from Martha's Vineyard, Massachusetts: Am. Jour. Scr., v. 257, p. 366-381. 
Olson, E. A., and Broecker, W. S., 1959, Lamont natural radiocarbon measurements V: Am. Jour. Sci. Radioc. Supp., v. 1, p. 1-28.

Olsson, Ingrid, 1960, Uppsala natural radiocarbon measurements II: Ам. Jour. Sci. Radioc. Supp., v. 2, p. 112-128.

Östlund, H. G., 1957, Stockholm natural radiocarbon measurements I: Science, v. 126, p. 493-497.

Overbeck, F., Münnich, K. O., Aletsee, L., and Averdieck, F. R., 1957, Das Alter des "Grenzhorizonts" norddeutsche Hochmoore nach Radiocarbon-Datierungen: Flora, v. 145 , p. $37-71$.

Pavlovskij, E. N., 1956, Quelques considérations sur les conditions écologiques de l'existence du mammouth: Internat. Cong. Zool., 14th, Copenhagen 1953, Proc., p. 61-63.

Posnansky, Merrick, in press, The neolithic cultures of East Africa: Pan-African Cong. on Prehistory, 4th, Leopoldville, Proc.

Preston, R. R., Person, Elaine, and Deevey, E. S., 1955, Yale natural radiocarbon measurements II: Science, v. 122, p. 954-960.

Rubin, Meyer, and Alexander, Corrinne, 1960, U. S. Geological Survey radiocarbon dates V: Am. Jour. Sci. Radioc. Supp., v. 2, p. 129-185.

Terasmae, Jaan, 1959, Notes on the Champlain Sea episode in the St. Lawrence lowlands, Quebec: Science, v. 130 , p. 334-336.

Tobias, P. V., Some developments in South African physical anthropology 1938-1958, in Galloway, Alexander, The skeletal remains of Bambandyanalo: Johannesburg, Witwatersrand Univ. Press, p. 127-154.

Tolmachoff, I, P. 1929 The carcasses of the mammoth and rhinoceros found in the frozen ground of Siberia: Am. Philos. Soc. Trans., n. s., v. 23, pt. 1, x, 74 p.

Trevor Jones, R., in press, Skeletal remains from Salisbury, Southern Rhodesia: PanAfrican Cong, on Pre-History, 4th, Leopoldville Proc. 